Nevada

Environmental

Restoration

Project

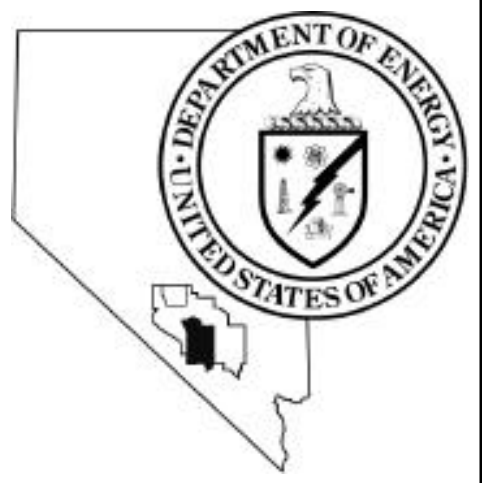

Addendum to the Corrective Action

Decision Docum ent/ Closure Report for Corrective Action Unit 232:

Area 25 Sewage Lagoons,

$\mathrm{N}$ evada Test $\mathrm{Site}, \mathrm{N}$ evada, R evision 0

Controlled Copy N $0 .:$

Addendum Revision $\bar{N} 0 .: 0$

May 2000

Approved for public release; further dissemination unlimited.

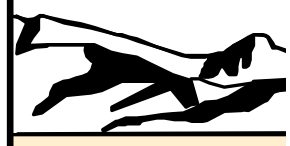

Environm ental Restoration

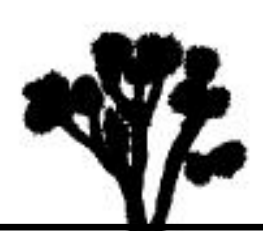

Division 
Available for sale to the public, in paper, from:

\author{
U.S. Department of Commerce \\ National Technical Information Service \\ 5285 Port Royal Road \\ Springfield, VA 22161 \\ Phone: 800.553 .6847 \\ Fax: 703.605.6900 \\ Email: orders@ntis.fedworld.gov \\ Online ordering: http//www.ntis.gov/ordering.htm
}

Available electronically at: http://www.doe.gov/bridge.

Available for a processing fee to U.S. Department of Energy and its contractors, in paper, from:

\author{
U.S. Department of Energy \\ Office of Scientific and Technical Information \\ P.O. Box 62 \\ Oak Ridge, TN 37831-0062 \\ Phone: 865.576.8401 \\ Fax: 865.576.5728 \\ Email: reports@adonis.osti.gov
}

Reference herein to any specific commercial product, process, or service by trade name, trademark, manufacturer, or otherwise, does not necessarily constitute or imply its endorsement, recommendation, or favoring by the United States Government or any agency thereof or its contractors or subcontractors. 


\section{ADDENDUM TO THE CORRECTIVE ACTION DECISION DOCUMENT/CLOSURE REPORT FOR CORRECTIVE ACTION UNIT 232: AREA 25 SEWAGE LAGOONS, NEVADA TEST SITE, NEVADA, REVISION 0}

DOE Nevada Operations Office

Las Vegas, Nevada

Controlled Copy No.:

Revision No.: 0

May 2000

Approved for public release; further dissemination unlimited. 


\section{ADDENDUM TO THE CORRECTIVE ACTION DECISION DOCUMENT/ CLOSURE REPORT FOR CORRECTIVE ACTION UNIT 232: AREA 25 SEWAGE LAGOONS, NEVADA TEST SITE, NEVADA, REVISION 0}

Approved by:

Date: $5 / 18 / 2000$

Janet Appenzeller-Wing, Project Manager

Industrial Sites Project

Approved by:

Date:

$5 / 18 / 2000$

Runore C. Wycoff, Division Director

Environmental Restoration Division 


\section{Preface}

This document is an addendum to the Corrective Action Decision Document/Closure Report for Corrective Action Unit 232: Area 25 Sewage Lagoons, Nevada Test Site, Nevada, DOE/NV--582-Rev. 0. This addendum provides the requested documentation that supports the assertion that contamination above levels of concern does not exist in the abandoned sewer lines.

The attached addendum summarizes the results of the manhole investigation conducted during March 2000. Results of the manhole investigation indicate that no changes to the Corrective Action Decision Document/Closure Report are necessary and all other sections of the document shall remain unchanged. 


\section{Addendum Summary}

During March 2000, personnel from Nevada Division of Environmental Protection (NDEP), U.S. Department of Energy (DOE), and IT Corporation inspected manholes associated with the Corrective Action Unit (CAU) 232 sewage lagoon to determine if an adequate volume of residual solids/sludges remain for analytical sampling. Sludge was not found in any of the manholes. The manholes contained trace amounts of soil particles and rodent excreta. In this region, the presence of rodent excreta heightens the probability for the hantavirus. The material in the manholes were not sampled because of insufficient volume and an analytical laboratory could not be identified to process samples potentially containing the hantavirus. The material found in the manholes appear to be incidental to post-operations system decay and passive influent, and therefore, not contaminated by operational discharges to the system. With concurrence from NDEP and DOE, the decision was made that further sampling would not be necessary at this CAU.

Table 1-1 describes the interior of the manholes investigated. Manholes MH-3 and MH-4 are located within the Test Cell C perimeter fence. Manholes MH-1 and MH A-4 are located outside the fence enroute to the sewage lagoons. Photographs of selected manholes are included in the Figures 1-1 through 1-4.

Table 1-1 Selected Manholes at CAU 232

\begin{tabular}{|c|l|}
\hline Manhole & \multicolumn{1}{|c|}{ Manhole Condition } \\
\hline \hline $\mathrm{MH}-1$ & $\begin{array}{l}\text { Insufficient sediment volume, dry, approx. 3 feet (ft) deep with ladder, orange lid marked "S," } \\
\text { more organic material than sediments, rodent excreta present }\end{array}$ \\
\hline $\mathrm{MH}-2$ & Photo not available. Insufficient sediment volume, rodent excreta present \\
\hline $\mathrm{MH}-3$ & $\begin{array}{l}\text { Insufficient sediment (gravel and soil) volume to sample, dry, approx. } 5 \text { to } 6 \mathrm{ft} \text { deep with ladder, } \\
\text { live bugs, rodent excreta present, snake skin }\end{array}$ \\
\hline $\mathrm{MH}-4$ & $\begin{array}{l}\text { Insufficient sediment volume, dry, approx. } 6 \mathrm{ft} \text { deep, chunks of concrete, misc. man-made debris, } \\
\text { live bugs, rodent excreta present }\end{array}$ \\
\hline $\mathrm{MH}$ A-4 & $\begin{array}{l}\text { Insufficient sediment volume, rodent excreta present, orange lid, moisture on lid and in open half } \\
\text { pipe, approx. 8 to 10 ft deep with ladder }\end{array}$ \\
\hline
\end{tabular}




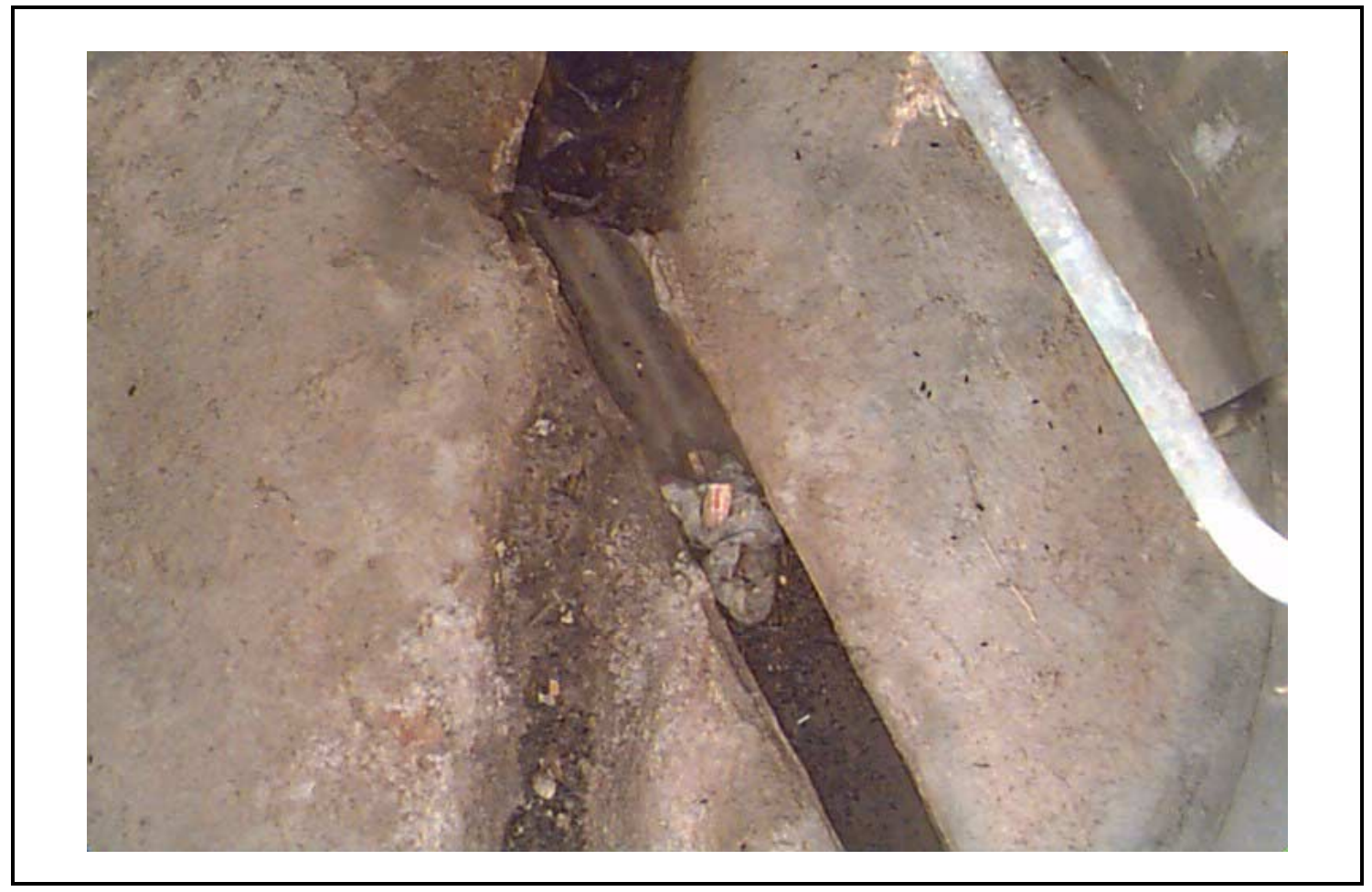

Figure 1-1 Manhole 1 (03/16/2000)

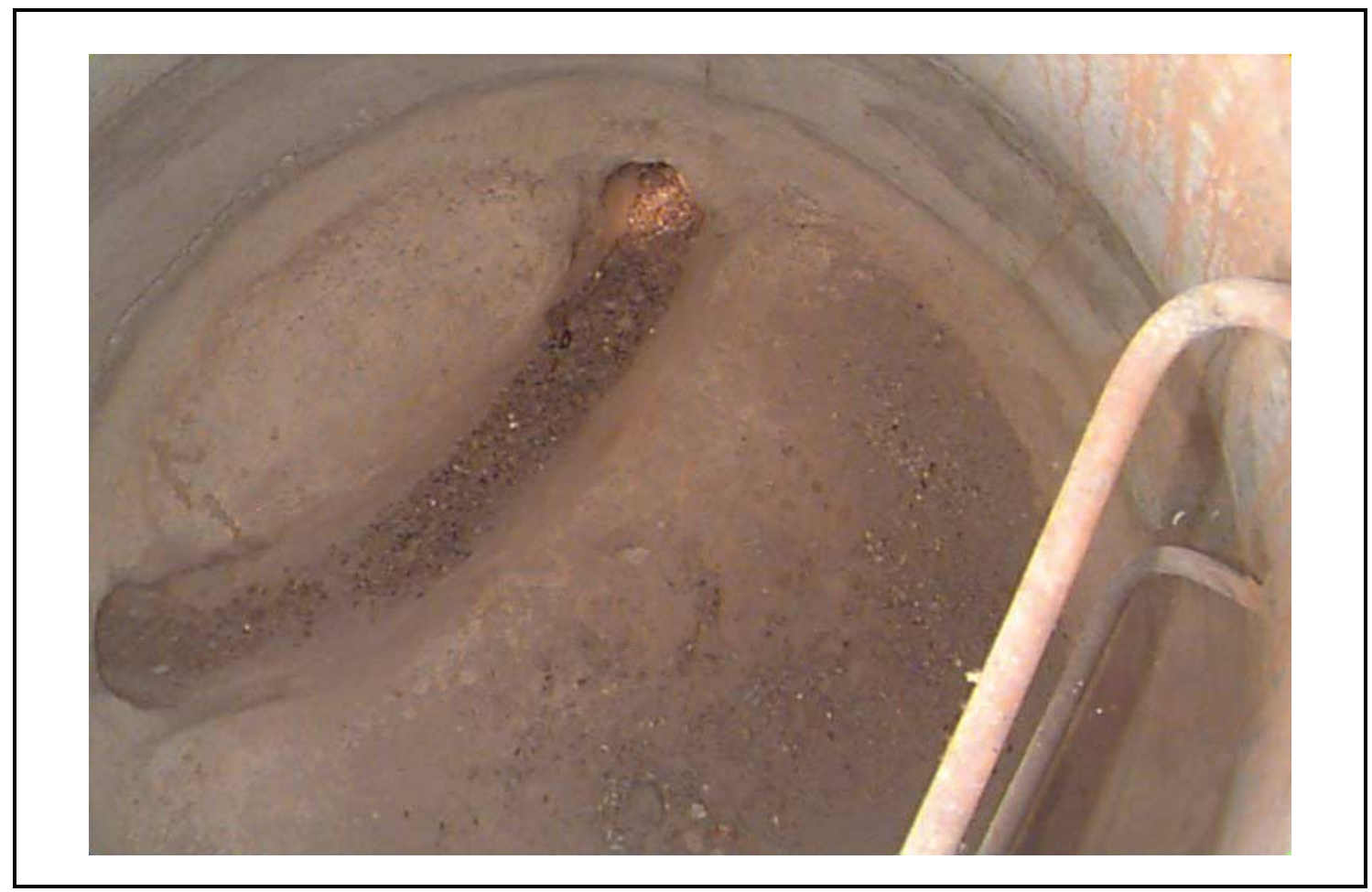

Figure 1-2 Manhole $3(03 / 16 / 2000)$ 


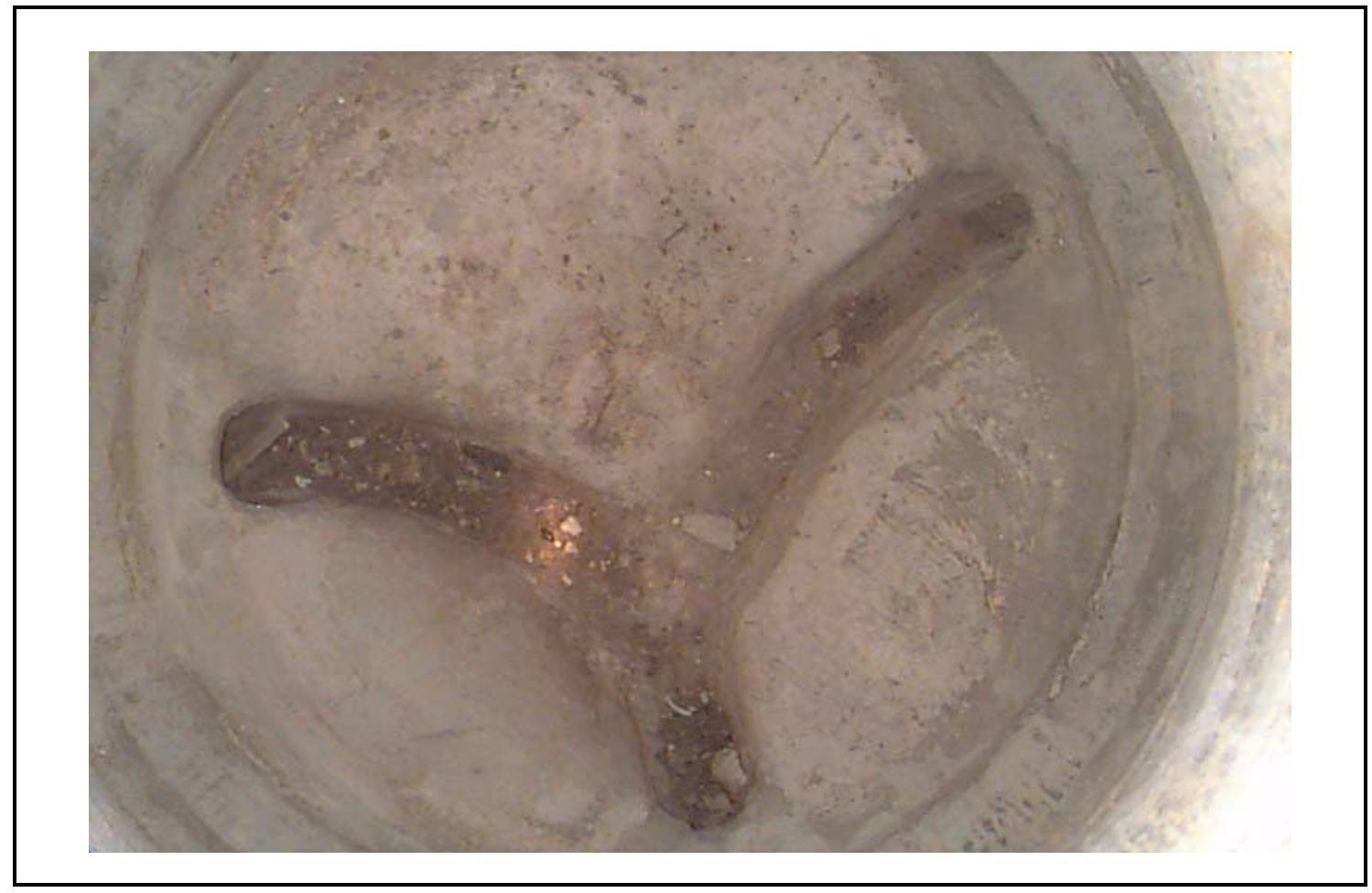

Figure 1-3 Manhole $4(03 / 16 / 2000)$

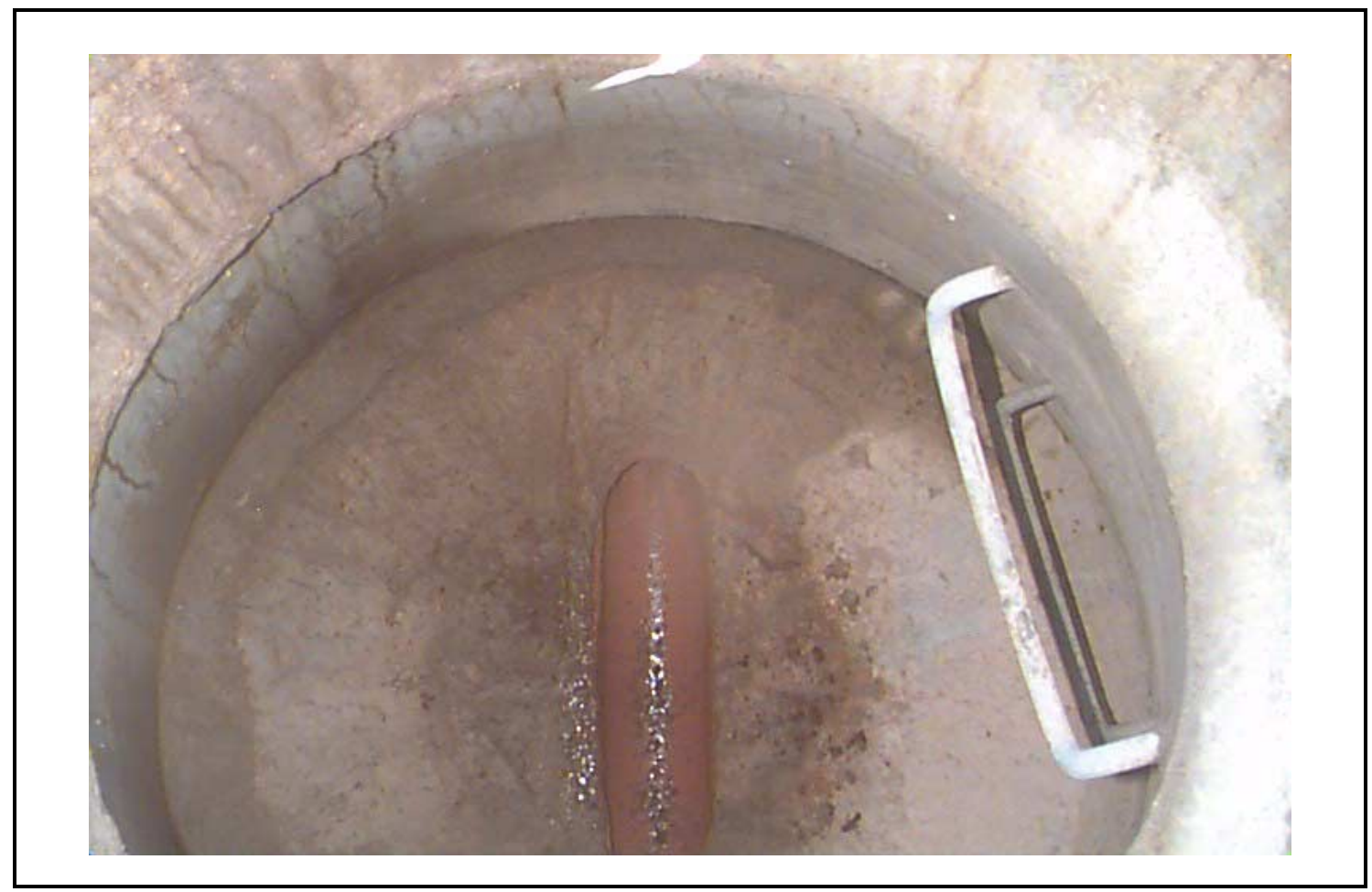

Figure 1-4 Manhole 4A (03/16/2000) 


\section{Distribution}

*Provide copy in distribution of Revision 0 and subsequent revisions if applicable.

Copies of the NDEP-approved document will be distributed to others.

Paul J. Liebendorfer

State of Nevada

Bureau of Federal Facilities

Division of Environmental Protection

333 W. Nye Lane, Room 138

Carson City, NV 89706-0851

Mike McKinnon

State of Nevada

Bureau of Federal Facilities

Division of Environmental Protection

555 E. Washington, Suite 4300

Las Vegas, NV 89101

Sabrina Lawrence

Environmental Restoration Division

DOE/Nevada Operations Office

P.O. Box 98518, M/S 505

Las Vegas, NV 89193-8518

Janet Appenzeller-Wing

Environmental Restoration Division

DOE/Nevada Operations Office

P.O. Box 98518, M/S 505

Las Vegas, NV 89193-8518

Sabine Curtis

Environmental Restoration Division

DOE/Nevada Operations Office

P.O. Box 98518, M/S 505

Las Vegas, NV 89193-8518

Jerry Bonn

Bechtel Nevada

P.O. Box 98521, M/S NTS306

Las Vegas, NV 89193-8521
2 (Controlled)*

1 (Controlled)*

1 (Controlled)*

1 (Uncontrolled)*

1 (Uncontrolled)*

1 (Uncontrolled)* 
Wayne Johnson

Bechtel Nevada

P.O. Box 98521, M/S NTS306

Las Vegas, NV 89193-8521

Linda Linden

SAIC

P.O. Box 93838

Las Vegas, NV 89193

Dustin Wilson

SAIC

P.O. Box 93838

Las Vegas, NV 89193

IT Corporation Central Files

IT Corporation

P.O. Box 93838

Las Vegas, NV 89193

Technical Information Resource Center

DOE/Nevada Operations Office

IT Corporation

P.O. Box 93838

Las Vegas, NV 89193

U.S. Department of Energy

Office of Scientific and Technical Information

P.O. Box 62

Oak Ridge, TN 37831

Manager Southern Nevada FFACO

Public Reading Room

P.O. Box 98521, M/S NLV040

Las Vegas, NV 89193-8521

Manager Northern Nevada FFACO

Public Reading Room

c/o Rosa Silver

IT Corporation

P.O. Box 93838

Las Vegas, NV 89193
1 (Uncontrolled)*

1 (Uncontrolled)*

1 (Uncontrolled)*

1 (Uncontrolled)*

1 (Uncontrolled)

1 (Uncontrolled, electronic copy)

1 (Controlled)

1 (Uncontrolled)

1 (Uncontrolled) 
FFACO Public Reading Rooms Coordinator

1 (Controlled)

Rosa Silver

IT Corporation

P.O. Box 93838

Las Vegas, NV 89193 